\title{
ABSTRACT
}

\section{Serving the Public Interest in Several Ways: Theory and Empirics*}

We develop a model where people differ in their altruistic preferences and can serve the public interest in two ways: by making donations to charity and by taking a public service job and exerting effort on the job. Our theory predicts that people who are more altruistic are more likely to take a public service job and, for a given job, make higher donations to charity. Comparing equally altruistic workers, those with a regular job make higher donations to charity than those with a public service job by a simple substitution argument. We subsequently test these predictions using cross-sectional data from Germany on selfreported altruism, sector of employment, and donations to charity. In addition, we use panel data from the Netherlands on volunteering and sector of employment. We find support for most of our predictions.

JEL Classification: D64, H11, J45, M50

Keywords: $\quad$ altruism, charitable donations, volunteering, public service motivation, public sector employment, self-selection

\author{
Corresponding author: \\ Robert Dur \\ Erasmus University Rotterdam \\ Department of Economics H9-15 \\ P.O. Box 1738 \\ 3000 DR Rotterdam \\ The Netherlands \\ E-mail: dur@ese.eur.nl
}

(c) $<2018>$. This manuscript version is made available under the CC-BY-NC-ND 4.0 license

http://creativecommons.org/licenses/by-nc-nd/4.0/ $\nearrow$

\footnotetext{
* We gratefully acknowledge comments and suggestions by two referees and a co-editor of this journal. We also thank seminar participants at Erasmus University Rotterdam and the University of Wisconsin-Madison, and participants of the 18th Colloquium on Personnel Economics at the Univerisity of Vienna, the ESOP Workshop on Work Motivation at the University of Oslo, the Dutch Economists Day 2016 in Amsterdam, the 2016 Workshop on Prosocial Motivation at Work at Erasmus University Rotterdam, and the 2017 CESifo Area Conference on Employment and Social Protection in Munich.
} 


\section{Introduction}

Many people feel a need to serve the public interest or to increase the wellbeing of others, even of complete strangers. Andreoni and Miller (2002) study such altruistic preferences in the lab and find that a majority of people are willing to spend some money (anonymously) in order to increase the well-being of unknown others. ${ }^{1}$ In practice, two common ways of serving the public interest are making a donation to charity and taking a job that involves helping others. Both these altruistic behaviors are prevalent in modern societies. List and Price (2012) report data showing that in rich countries typically more than half of the population make donations to charity. Data from the International Social Survey 2015 suggest that many people aspire and many have a job in which they can increase the well-being of others, see the first column of Table 1.

In this paper we develop a coherent framework to study the role of altruistic preferences in job choice, on-the-job effort provision, and charitable donations. We set up a simple theoretical model, and subsequently test the model's predictions using rich survey data. In our model, people differ in their altruism and can serve the public interest in two ways: by making a charitable donation and by taking a public service job and exerting effort on the job. People make three decisions: whether to take a public service job or a regular job, how much effort to exert at work, and how much of their income to donate to charity.

Our theoretical analysis yields the following predictions. First, as in related models that we discuss below, the likelihood of having a public service job (weakly) increases in a worker's altruism. The reason is that holding a public service job gives opportunities to contribute to the well-being of others at relatively low cost, which is appreciated by - and hence attracts altruistic workers. Second, and quite naturally, for a given job type, charitable donations (weakly) increase in workers' altruism. Third, and perhaps more surprising, for a given altruism and income, workers holding a regular job donate more to charity than workers holding a public service job. The intuition behind this result is that public service workers already contribute to the well-being of others by exerting effort on the job and, hence, by a substitution argument, they donate less.

Our study is related to a rapidly expanding theoretical literature in eco-

\footnotetext{
${ }^{1}$ See also Beckman et al. (2002) and Falk et al. (2005), among others.
} 
nomics studying self-selection and workplace behavior of intrinsically motivated workers, see for example Francois (2000, 2007), Besley and Ghatak (2005, 2017), Prendergast (2007), Delfgaauw and Dur (2007, 2008), Brekke and Nyborg (2008), Dal Bó et al. (2013), Dur and Zoutenbier (2015), Manna (2016), Cassar (2016a), and Barigozzi and Burani (2016). In many of these studies, intrinsic motivation takes the form of altruism. We enrich this literature by allowing workers to serve the public interest in several ways - not only by exerting effort on certain types of jobs, but also by making charitable donations outside of work.

Our theoretical predictions point to a possible flaw in the empirical literature. Numerous public administration scholars and several economists have examined whether workers in some sectors or job types are more altruistic than in others (see Perry et al. 2010 and Perry and Vandenabeele 2015 for overviews). Many of these studies measure a worker's altruistic preferences using data on the worker's behavior outside the workplace, among others on the worker's donations to charity (e.g. Brewer 2003, Houston 2006, Rotolo and Wilson 2006, Carpenter and Myers 2010, Lee 2012, Piatak 2015, and Ayaita et al. 2017). Our theory suggests that this measure is flawed and leads to an underestimation of altruism of workers in public service jobs. Indeed, our theory does not rule out that workers in public service jobs on average donate less to charity than workers in regular jobs do, and yet are more altruistic. This is particularly likely when public service jobs offer ample opportunities to serve the public interest, such that workers in those jobs feel less of a need to make further contributions outside the workplace. ${ }^{2}$

We empirically examine our predictions using data from the German Socio-Economic Panel Study (SOEP). ${ }^{3}$ The SOEP is a representative longitudinal study covering 30,000 persons in 11,000 households. It contains

\footnotetext{
${ }^{2}$ See Buurman et al. (2012) and Tonin and Vlassopoulos (2015) for related, though less precise, arguments. Another related paper is the recent study by Aldashev et al. (2016) that examines rent extraction, charitable donations, and self-selection of altruistic and selfish managers into for-profit and not-for-profit organizations, and finds that multiple equilibria may arise. Our theory also relates to the literature on moral licensing in social psychology, which posits that people tend to take immoral decisions following past good deeds (see Merritt et al. (2010) for a recent review).

${ }^{3}$ Dur and Zoutenbier (2015) use the same panel to study selection of altruistic and lazy workers into the public sector in Germany. The regressions reported in Table 7 below replicate their results using a newer wave. The other two predictions developed in this paper as well as the corresponding regressions reported in Tables 4, 5, and 6 are completely new.
} 
questions about individual's education, earnings, employment, personality characteristics, and behavior. The key variables that we use for our analysis are self-reported altruism, money donations to charity, and job type or sector of employment. Following Becker et al. (2012) and Dur and Zoutenbier (2015), we measure a worker's altruism by his response to the question: "How important do you find it to be there for others currently?" Donations to charity are measured by the response to the question: "Did you donate money last year (not counting membership fees)?" If the answer to this question is yes, the respondent is asked to report the total amount donated. Lastly, in line with the literature, we use several definitions of what a public service job exactly is. ${ }^{4}$

Consistent with our theory, we find that workers who are more altruistic are more likely to take a public service job and, for a given job type, donate a higher amount to charity. Furthermore, we find that workers in a regular job make significantly higher donations to charity than equally altruistic workers in a public service job. However, this difference moves close to zero and becomes statistically insignificant when we control for income. Moreover, the result turns out to be sensitive to the estimation method. For the subsamples of highly educated workers and male workers we find results that are more supportive for our predictions, and we discuss reasons for why this is plausible.

We complement our analysis of the German cross-sectional data with an analysis of Dutch panel data. An advantage of this dataset is that it allows us for a subset of the sample to observe the same workers at different points in time in different job types. Assuming that a worker's altruism is stable over time, the prediction is that a worker makes smaller charitable contributions when working in a public service job than when working in a regular job. As the Dutch data lack precise information on money donations,

\footnotetext{
${ }^{4}$ In the literature there is no agreement on what a public service job exactly is. Following Perry and Wise (1990)'s concept of public service motivation, many papers compare workers employed in the public sector with those employed in the private sector, for example Vandenabeele (2008), Steijn (2008), and Christensen and Wright (2011). Other papers also compare workers employed in different industries or job types, see for example Gregg et al. (2011), Houston (2011), Christensen and Wright (2011), and Kjeldsen and Jacobsen (2013). In our empirical work we use two definitions. First, we define public service jobs as jobs in the public sector and regular jobs as jobs in the private sector. Later, we define public service jobs as jobs in certain industries (health, sport and education, and public administration) and regular jobs as jobs in the remaining industries. The results we obtain are roughly the same.
} 
we use hours of voluntary work as our main outcome measure instead. We find some support for our prediction in the Dutch data, in particular for older workers. Following Zoutenbier (2016), we also use the Dutch data in another way, examining how a match of mission preferences for government workers affects those workers' hours of voluntary work. The prediction is that government workers whose political preferences align with those of the government have better opportunities to do good on the job, weakening the urge to do voluntary work outside the job. Also for this prediction we find some support in the data.

Studying workers' charitable behavior and self-selection into jobs is interesting in itself as well as relevant from a policy perspective. Studies like ours contribute to the body of knowledge about the prevalence of work motivations in different job types and sectors, which can be used when designing HR-policies. Moreover, as our study provides insights into the drivers of charitable donations and volunteering, our results may be useful for not-for-profit organizations in designing and targeting their promotion and recruitment activities.

An essential assumption underlying our theory is that jobs differ in the opportunities they give workers to serve the public interest. Table 1 shows some recent data supporting this assumption. The International Social Survey 2015 asked workers whether they can help other people in their job and whether their job is useful to society. Workers holding a public sector job report significantly higher scores on both dimensions as compared to workers holding a private sector job. Lockwood et al. (2017) review estimates of the economy-wide externalities generated in a number of professions, showing positive and substantial externalities for teaching and research and negative externalities for finance and law. The number of professions for which an estimate is available is, however, very limited.

The remainder of this paper is organized as follows. In the next section we develop and analyze our theoretical model and derive predictions. In Section 3 we describe the German cross-sectional data, the empirical strategy, and our empirical results. Section 4 tests our key prediction using Dutch panel data. Section 5 concludes. 


\section{Theory}

\section{$2.1 \quad$ Model}

We develop a model where workers take three decisions: they choose between a regular job $(s=0)$ and a public service job $(s=1)$, how much effort to exert on the job $\left(e_{s, i} \geq 0\right)$, and how much of their income to donate to charity $\left(d_{s, i} \geq 0\right)$. Workers are heterogeneous in two ways. First, they differ in their altruism denoted by $\gamma_{i}$. We assume altruism is impure, as in Andreoni (1990). That is, a worker receives a 'warm-glow' utility from making a contribution to the well-being of others, but he does not directly care about others' utility. This approach is in line with earlier related models such as Besley and Ghatak (2005), Delfgaauw and Dur (2008), Dur and Zoutenbier (2015), and Aldashev et al. (2016). ${ }^{5}$ Tonin and Vlassopoulos (2010) provide field-experimental evidence supporting this assumption. The altruism parameter $\gamma_{i}$ follows a continuous distribution with boundaries $[0, \bar{\gamma}]$ with $\bar{\gamma}>0$. Second, workers differ in a fixed benefit (or cost) from choosing a public service job, denoted by $\varepsilon_{i}$. This variable is meant to represent worker $i$ 's preference for job aspects other than those stressed by our theory, such as commuting time, pension plans, and other job (dis)amenities. $\varepsilon_{i}$ is drawn from a continuous distribution with boundaries $[\underline{\varepsilon}, \bar{\varepsilon}]$ where $\underline{\varepsilon}<0<\bar{\varepsilon}$. We shall assume a sufficiently rich type space (sufficiently low $\underline{\varepsilon}$ and sufficiently high $\bar{\varepsilon}$ ), so that in equilibrium any possible altruism type $\gamma_{i}$ is present in both types of jobs.

A worker's utility depends on his private consumption, on his cost of effort, the fixed benefit or $\operatorname{cost} \varepsilon_{i}$ when working in a public service job $(s=1)$, and - if the worker is altruistic $\left(\gamma_{i}>0\right)$ - on his contribution to the wellbeing of others. More specifically, we assume that worker $i$ 's utility increases linearly in his private consumption, that his effort costs are quadratic, and that his 'altruistic utility' is log-linear in his contributions to the well-being of others: ${ }^{6}$

$$
U_{i}\left(d_{s, i}, e_{s, i}\right)=w_{s, i}-d_{s, i}-\frac{1}{2} \theta e_{s, i}^{2}+\gamma_{i} \ln \left(d_{s, i}+\beta_{s} e_{s, i}\right)+s \varepsilon_{i},
$$

\footnotetext{
${ }^{5}$ For an overview of theoretical papers applying different types of altruism, see Francois and Vlassopoulos (2008).

${ }^{6}$ The linearity of utility in private consumption implies that we abstract from income effects. This greatly simplifies the analysis. In the empirics, we run analyses with and without controlling for income.
} 
where $w_{s, i}$ denotes worker $i$ 's wage when working in sector $s$, private consumption is the difference between the worker's wage $\left(w_{s, i}\right)$ and his donation to charity $\left(d_{s, i} \geq 0\right)$, the parameter $\theta$ is a measure for the cost of effort, and $\beta_{s}$ is the effect of a unit of effort in job type $s$ on the well-being of others. For simplicity, we assume $\beta_{0}=0$ and $\beta_{1}>0$. That is, only effort in a public service job increases the well-being of others, while effort in a regular job does not. However, our key predictions are similar if on-the-job effort would increase the well-being of others in both job types but more so in public service jobs, which is in line with the available empirical evidence discussed in the Introduction. Besides exerting effort in a public service job, workers in either type of job can serve the public interest by donating money to charity, and we assume that these two instruments are perfect substitutes. Furthermore, we assume that workers are paid for performance in regular jobs, while workers receive a flat wage in a public service job. More precisely, wages in regular and public service jobs equal $w_{0}=a+x e_{0}$ and $w_{1}=z$, respectively, where $x$ equals the marginal product of effort of workers in a regular job (assuming perfect competition in the labor market) and $z$ is such that the demand for public services equals the supply of those services provided by workers in public service jobs in equilibrium. The assumption of flat wages in public service jobs is in line with the stylized fact that pay is typically less dependent on performance in those jobs. ${ }^{7}$ Our key predictions need not change if we allow for performance pay in all jobs.

The timing of the events is as follows. First, nature draws each worker's $\gamma_{i}$ and $\varepsilon_{i}$. Second, workers choose either a regular or a public service job. Finally, workers choose their effort and donations.

\subsection{Analysis}

We solve the model by backward induction and first derive the on-the-job effort and charitable donations a worker chooses for a given job type. Next, we will analyze which worker types, in terms of $\gamma_{i}$ and $\varepsilon_{i}$, sort into which job type. Along the way, we will formulate predictions that will be empirically examined in Sections 3 and 4.

If worker $i$ has a regular job $(s=0)$, his optimization problem reads

\footnotetext{
${ }^{7}$ For example, Burgess and Metcalfe (1999) report that incentive pay is more prevalent in private sector jobs than in public sector jobs. Likewise, in the education industry, pay is generally based on experience and academic degrees and not on effort or performance, see e.g. Podgursky (2007).
} 


$$
\max _{e_{0, i}, d_{0, i}} a+x e_{0, i}-d_{0, i}-\frac{1}{2} \theta e_{0, i}^{2}+\gamma_{i} \ln \left(d_{0, i}\right) .
$$

Optimal effort $e_{0, i}^{*} \geq 0$ and optimal donations $d_{0, i}^{*} \geq 0$, are found by simultaneously solving the following first-order conditions:

$$
\begin{gathered}
\frac{\partial U(\cdot)}{\partial e_{0, i}}=x-\theta e_{0, i}^{*}=0, \\
\frac{\partial U(\cdot)}{\partial d_{0, i}}=-1+\frac{\gamma_{i}}{d_{0, i}^{*}}=0,
\end{gathered}
$$

which results in:

$$
\begin{aligned}
e_{0, i}^{*} & =\frac{x}{\theta}, \\
d_{0, i}^{*} & =\gamma_{i} .
\end{aligned}
$$

Hence, workers with a regular job all exert the same level of effort, independent of their altruistic preferences. ${ }^{8}$ Altruistic workers with a regular job donate a part of their income to charity, and the more so the stronger their altruistic preferences. Selfish workers (those with $\gamma_{i}=0$ ) would like to extract money from charities $\left(d_{0, i}^{*}<0\right)$, but the non-negativity constraint naturally prevents this, and so their donations equal zero.

If worker $i$ has a public service job, his optimization problem reads

$$
\max _{e_{1, i}, d_{1, i}} z-d_{1, i}-\frac{1}{2} \theta e_{1, i}^{2}+\gamma_{i} \ln \left(d_{1, i}+\beta_{1} e_{1, i}\right)+\varepsilon_{i} .
$$

Optimal effort $e_{1, i}^{*} \geq 0$ and optimal charitable donations $d_{1, i}^{*} \geq 0$ are found by simultaneously solving the first-order conditions:

$$
\begin{gathered}
\frac{\partial U(\cdot)}{\partial e_{1, i}}=-\theta e_{1, i}^{*}+\frac{\gamma_{i} \beta_{1}}{d_{1, i}^{*}+\beta_{1} e_{1, i}^{*}}=0, \\
\frac{\partial U(\cdot)}{\partial d_{1, i}}=-1+\frac{\gamma_{i}}{d_{1, i}^{*}+\beta_{1} e_{1, i}^{*}}=0,
\end{gathered}
$$

which gives after solving:

$$
\text { if } \gamma_{i} \leq \frac{\beta_{1}^{2}}{\theta} \Rightarrow e_{1, i}^{*}=\sqrt{\frac{\gamma_{i}}{\theta}} \text { and } d_{1, i}^{*}=0 \text {; }
$$

\footnotetext{
${ }^{8}$ This stems from the assumption that utility increases linearly in private consumption.
} 


$$
\text { if } \gamma_{i}>\frac{\beta_{1}^{2}}{\theta} \Rightarrow e_{1, i}^{*}=\frac{\beta_{1}}{\theta} \text { and } d_{1, i}^{*}=\gamma_{i}-\frac{\beta_{1}^{2}}{\theta} \text {. }
$$

Clearly, not all of the altruistic workers in a public service job make donations to charity. Those with altruism lower than or equal to $\beta_{1}^{2} / \theta$ only exert effort and do not supplement it by making charitable donations. The reason for this is that, up to some point, exerting effort on the job is a less costly way to serve the public interest than making charitable donations. Consequently, workers with relatively low levels of altruism will only make use of this less costly instrument, and the more so, the more altruistic the worker is. When work effort reaches a critical level, making charitable donations becomes the less costly option at the margin. As a result, workers whose altruism is higher than $\beta_{1}^{2} / \theta$ use both effort and donations to serve the public interest. Note that starting at the threshold level of altruism of $\beta_{1}^{2} / \theta$, higher altruism results in an increase in donations, while effort remains the same. Thus, as compared to models where people can only serve the public interest through on-the-job effort, we find that adding the option to make charitable donations truncates effort for public service jobs. Note that the level at which effort is truncated critically depends on the effectiveness of effort as compared to that of charitable donations, as measured by $\beta_{1}$. Clearly, when on-the-job effort is more effective in raising the well-being of others, effort plays a bigger role at the expense of charitable donations. Lastly, note that (2), (3), and (4) imply that, for a given altruism, a worker's charitable donations are always higher when holding a regular job as compared to holding a public service job. The reverse holds, however, for total contributions to the public interest $(d+\beta e)$ for workers with altruism smaller than $\beta_{1}^{2} / \theta$. The intuition is that workers with a public service job can contribute to the public interest at a lower cost, and hence contribute more. For workers with altruism equal to or higher than $\beta_{1}^{2} / \theta$, total contributions are the same across job types for a given level of altruism. The reason is that, for those workers, the marginal costs of charitable donations drives their total contribution, which is independent of job type.

The choices that workers make are depicted in Figure 1.

[Figure 1]

In Section 3, we will use cross-sectional data to examine the following predictions regarding worker's charitable donations: 
Prediction 1: For a given job, charitable donations (weakly) increase in a worker's altruism.

Prediction 2: For a given worker's altruism, charitable donations are higher when holding a regular job as compared to when holding a public service job.

We shall examine whether these predictions find support in the data, with and without controlling for worker's income in the regressions. In Section 4, we confront prediction 2 with panel data.

Now that we have analyzed the behavior of workers in a given job type, we examine which worker types sort into which job type. Substituting (1) and (2) into the utility function gives, after some rewriting, the utility derived from taking a regular job:

$$
U_{i}\left(d_{0, i}, e_{0, i}\right)=a+\frac{x^{2}}{2 \theta}-\gamma_{i}+\gamma_{i} \ln \left(\gamma_{i}\right)
$$

Workers taking a public service job attain utility:

$$
\begin{aligned}
& U_{i}\left(d_{1, i}, e_{1, i}\right)=z-\frac{\gamma_{i}}{2}+\gamma_{i} \ln \left(\beta_{1} \sqrt{\frac{\gamma_{i}}{\theta}}\right)+\varepsilon_{i} \text { when } \gamma_{i} \leq \frac{\beta_{1}^{2}}{\theta} ; \\
& U_{i}\left(d_{1, i}, e_{1, i}\right)=z+\frac{\beta_{1}^{2}}{2 \theta}-\gamma_{i}+\gamma_{i} \ln \left(\gamma_{i}\right)+\varepsilon_{i} \text { when } \gamma_{i}>\frac{\beta_{1}^{2}}{\theta},
\end{aligned}
$$

which follows from substituting (3) and (4) into the utility function. Comparing the utilities attained in a regular and public service job, it follows that workers with $\gamma_{i} \leq \beta_{1}^{2} / \theta$ choose a public service job if:

$$
z-a-\frac{1}{2} \frac{x^{2}}{\theta}+\frac{1}{2} \gamma_{i}+\gamma_{i} \ln \left(\beta_{1} \sqrt{\frac{\gamma_{i}}{\theta}}\right)-\gamma_{i} \ln \left(\gamma_{i}\right)+\varepsilon_{i} \geq 0 .
$$

There is an interior solution for any possible $\gamma$-type if $\bar{\varepsilon}$ is sufficiently large and $\underline{\varepsilon}$ is sufficiently low. It is also straightforward to derive that the left-hand side of the inequality increases with $\gamma_{i}$. Hence, for workers whose altruism is smaller than or equal to $\beta_{1}^{2} / \theta$, it holds that those with stronger altruistic preferences are more likely to choose a public service job. The intuition is that a public service job offers an opportunity to serve the public interest at a relatively low cost, which is more attractive for workers with stronger 
altruistic preferences as they make more use of it. For workers with $\gamma_{i}>$ $\beta_{1}^{2} / \theta$, we find that they prefer a public service job if:

$$
z-a+\frac{\beta_{1}^{2}}{2 \theta}-\frac{x^{2}}{2 \theta}+\varepsilon_{i} \geq 0
$$

Hence, for these highly altruistic workers, the attractiveness of a public service job does not increase with the worker's altruism. The reason is that all workers within this group use the opportunity to serve the public interest on the job to the same extent, see equation (4) above. Hence, the probability of choosing a public service job does not further increase with altruism starting at $\gamma_{i}=\beta_{1}^{2} / \theta$.

The preferences for job type are depicted in Figure 2.

\section{[Figure 2]}

In equilibrium, the wage for public service jobs $z$ will be such that supply of and demand for services are equal:

$$
\int_{0}^{\gamma^{*}} \int_{\varepsilon(\gamma)}^{\bar{\varepsilon}} \sqrt{\frac{\gamma_{i}}{\theta}} f(\varepsilon, \gamma) d \varepsilon d \gamma+\int_{\gamma^{*}}^{\bar{\gamma}} \int_{\varepsilon\left(\gamma^{*}\right)}^{\bar{\varepsilon}} \frac{\beta_{1}}{\theta} f(\varepsilon, \gamma) d \varepsilon d \gamma=D
$$

where $\gamma^{*}=\beta_{1}^{2} / \theta, \varepsilon(\gamma)$ is the relation resulting from condition (5) holding with equality, $f(\varepsilon, \gamma)$ is the probability density function, and $D$ represents the demand for public services measured in units of effort (which may well depend on the cost per unit, but is assumed to be constant here for convenience). Without loss of generality, we assume a mass of workers equal to unity. Note that when $z$ goes up, $\varepsilon(\gamma)$ goes down, implying an increase in supply. Note also that whether in equilibrium a negative or positive wage differential arises for public service jobs depends crucially on the distribution of the fixed job benefit $\varepsilon$, the supply of altruistic workers as captured by the distribution of $\gamma$, as well as on the size of the demand for public services $D$.

The prediction that will be studied in Section 3 resulting from the analysis of job choice is:

Prediction 3: Workers who are more altruistic are (weakly) more likely to choose a public service job. 


\section{Empirical evidence from Germany}

\subsection{Data and Empirical Strategy}

In this section we use data from the German Socio-Economic Panel Study (SOEP). ${ }^{9}$ The SOEP is an unbalanced panel which contains survey questions about employment, earnings, preferences, and personality measures among others (see Wagner et al. 2007). Our key variables of interest are selfreported monetary donations to charity, altruistic preferences, and job type or sector of employment. We measure charitable donations by the response to the question: "Did you donate money last year (not counting membership fees)?"10 The respondents who answered this question with "yes" were subsequently asked how much money they donated in total. Following Becker et al. (2012) and Dur and Zoutenbier (2015), we measure altruistic preferences by the respondent's answer to the question: "How important are the following things [being there for others] currently for you?" Answers are given on a four point scale, ranging from "not at all important" to "very important". Finally, we allow for two distinct definitions of what regular and public service jobs are. We start with defining public service jobs as jobs in the public sector and regular jobs as jobs in the private sector. ${ }^{11}$ Next, we define public service jobs as jobs in certain industries (health, sport and education, and public administration) and regular jobs as jobs in the remaining industries. We exclude all people without a job from our sample.

One may be sceptical about the reliability of the questionnaire data we use, particularly about the self-reported altruistic preferences and donations. For instance, it might well be that people paint a too rosy picture of their altruistic preferences and their generosity. Even worse, such misrepresentation may correlate with job type. Recent findings from an incentivized experiment by Abeler et al. (2014), however, suggest that we should not be too sceptical about self-reported data. They find among a representative sample of the German population that participants forego considerable amounts

\footnotetext{
${ }^{9}$ Detailed information about the SOEP can be found at http://www.diw.de/en/soep.

${ }^{10}$ In the questionnaire, it is further stated that "We understand donations here as giving money for social, church, cultural, community, and charitable aims, without receiving any direct compensation in return. These donations can be large sums of money but also smaller sums, for example, the change one puts into a collection box. We also count church offerings."

${ }^{11}$ Unfortunately, it is not possible to distinguish between for-profit and not-for-profit employers in the private sector. This likely results in a downward bias in our estimates.
} 
of money to avoid lying. ${ }^{12}$ Moreover, they do not find any robust correlations between lying behavior and individual characteristics, including sector of employment (Abeler et al. 2014). ${ }^{13}$ Relatedly, Falk et al. (2016) examine the predictive power of survey questions for incentivized choices and find a sizeable correlation of 0.4 between stated and revealed willingness to donate part of a windfall gain to a charity.

We restrict our analysis to the year 2010, because this is the only year in which the question about charitable donations is included in the survey. The question that measures a respondent's altruism is taken from the 2008 wave, which is the most recent wave that includes this question. We have a sample of 7,527 respondents of which $26.2 \%$ is employed in the public sector and the remaining $73.8 \%$ is employed in the private sector (the corresponding figures for the alternative definition of a public service job are $33.0 \%$ and $67.0 \%$ ).

To examine whether there is support for our predictions 1 and 2, we run an ordinary least squares (OLS) regression with money donations to charity as the dependent variable. ${ }^{14}$ Our main specification is:

$$
C=\alpha+\beta \cdot A+\psi \cdot S+\kappa \cdot I+\phi \cdot X+\eta,
$$

where $C$ is the amount of charitable donations, $A$ is a worker's self-reported altruism, $S$ is a dummy variable that equals one if a worker has a public service job, $I$ is worker's income, $X$ is a vector of other control variables, and $\eta$ is the residual. In line with theoretical predictions 1 and 2, we expect that, for a given job type, an increase in altruism leads to an increase in donations $(\beta>0)$ and that, for a given altruism, having a public service job instead of a regular job decreases donations $(\psi<0)$. While our theoretical model abstracts from income effects, we allow for those in the empirical analysis by including the worker's income.

To examine theoretical prediction 3 regarding the altruism of workers

\footnotetext{
${ }^{12}$ See also Abeler et al. (2016) who use data from 72 experimental studies and find that people lie surprisingly little.

${ }^{13}$ Evidence based on similar experiments in other countries is mixed. While Barfort et al. (2017) find that honesty and a preference for public service jobs are positively correlated for a sample of Danish students, Banerjee et al. (2015) and Hanna and Wang (2017) find the reverse for students in India, while Alatas et al. (2009) find no correlation for Indonesian students.

${ }^{14}$ As a robustness check, we also estimated a tobit model and a negative binomial regression model, and found very imprecise estimates with those models.
} 
with a public service job, we estimate the following linear probability model:

$$
S=\delta+\mu \cdot A+\lambda \cdot Z+\omega
$$

where $S$ is a dummy variable equal to one if the worker has a public service job, $A$ is the worker's altruism, $Z$ is a vector of other control variables, and $\omega$ is the residual. In line with theoretical prediction 3 we expect that workers' probability to sort into a public service job increases in altruism $(\mu>0)$. The specification we estimate is identical to Dur and Zoutenbier (2015) who study the same issue using an earlier wave of the German Socio-Economic Panel. Following the terminology in Clemens (2017), this part of our analysis can be described as a form of replication called reproduction test.

In Table 2 we display the descriptive statistics of our sample. Since in most of our empirical analysis we compare public sector workers with private sector workers, we distinguish between these two in the descriptive statistics as well. There are several striking differences between public and private sector workers. For instance, the average donation made by public sector workers is 121.95 euros, while private sector workers on average donate 107.37 euros. There is quite a bit of variation in donations in both sectors. Public sector workers report to be more altruistic than private sector workers, though the difference in the average is small. Furthermore, public sector workers are on average older, are more often female, and are much higher educated than private sector workers. Also, public sector workers earn on average a higher yearly income, while the standard deviation of their income is much lower than the standard deviation of incomes in the private sector.

Table 3 shows the correlations between our variables of interest. Charitable donations and altruism are positively correlated and the same is true for charitable donations and public sector employment and for altruism and public sector employment. Figure 3 plots the average charitable donations by sector of employment and altruism. Charitable donations tend to increase with a worker's altruism. ${ }^{15}$ Moreover, it turns out that, for a given altruism, public sector workers on average donate more than private sector workers. While this runs counter to our theoretical predictions, we should keep in mind that these are raw correlations, which do not control for important heterogeneity between public and private sector employees, among

\footnotetext{
${ }^{15}$ Note that none of the respondents in the lowest altruism category (those who state that they find it not important at all to be there for others) donate any money to charity. Hence the lack of bars for this category in Figure 3.
} 
others in education, gender, and income. To control for these, we now turn to regression analysis.

[Figure 3]

\subsection{Results}

Table 4 reports the results of regressing charitable donations (measured in euros) on a worker's altruism, sector of employment, and a rich set of demographics. We include altruism in the most flexible manner, i.e. we take up three dummies for altruism categories 1, 2, and 4, while category 3 -workers who answered they find it "important" to be there for others- forms the baseline category. We find evidence in line with predictions 1 and 2. That is, charitable donations increase with self-reported altruism and, for a given level of altruism, public sector workers donate significantly less than private sector workers. The difference is 32.51 euro, which is close to $30 \%$ of mean donations. The second column of Table 4 adds the worker's income as a control in a very flexible manner by taking up 10 dummies for income categories. The estimates (not reported for brevity) show a positive convex relation between donations and income. More importantly, controlling for income moves the coefficient for public sector employment close to zero. Clearly, without controlling for income, the public sector dummy picked up that workers in the public sector make smaller donations because they earn less than comparable others in the private sector. Many of the other control variables have the same sign and are of similar size as compared to earlier studies. For example, highly educated workers donate more than lower educated workers (cf. Bekker and Wiepking 2011), though the difference decreases with almost 40 percent when controlling for income. Contrary to earlier studies (e.g. Mesch et al. 2006 and Piper and Schnepf 2008), we don't find that females donate more than males. However, we should keep in mind that, in contrast to earlier studies, our regressions control for self-reported altruism, which is strongly correlated with gender (see Table 3 ).

Table 5 shows the same regressions using a different definition of a public service job, namely jobs in the health industry, sport and education industry, and public administration. ${ }^{16}$ Column 1 and 2 show results that are quali-

\footnotetext{
${ }^{16}$ The other industries are: agriculture, fisheries, energy/water, mining, chemicals, synthetics, earth/clay/stone, iron/steel, mechanical engineering, electiral engineering, wood/paper/print, clothing, food, construction, wholesale, trading agents, retail, train
} 
tatively the same as those in Table 4, even though the coefficient for public service job is smaller and far from significant even when we do not control for income. In column 3 and 4 we estimate the regressions with dummies for each of the public service industries separately. We find that the negative coefficient for public service jobs is driven by workers in public administration who donate 55.23 euro less than similarly altruistic workers in other industries (26.66 euro less after controlling for income).

All our results so far are based on the full sample of workers. Motivated by Lewis and Frank (2002), Buurman et al. (2012), and Dur and Zoutenbier (2015) we replicated our results using a subsample of highly educated workers, defined as those who completed more than high school only. The main reason for looking at this subsample is that it might be that highly educated workers have more on-the-job opportunities to serve the public interest than less educated workers. Our results are in line with this, see Table 6 column 1 and 2. We find that for the subsample of highly educated workers, working in the public sector goes hand in hand with much lower charitable donations, a difference that remains substantial (but loses significance) even when we control for income. In the third and fourth column of Table 6 , we analyze the subsample of male workers. Male and female workers may differ in their cost of effort at work (measured by $\theta$ ) because women tend to perform more household work and child care. As a result, the difference between charitable donations made by regular workers and public service workers may be bigger for male workers than for female workers, see (2), (3), and (4), or see Figure 1. The results in the third and fourth column of Table 6 are in line with this.

Lastly, we examine selection into type of job. Table 7 reports the results of a linear probability model similar to Dur and Zoutenbier (2015), where the dependent variable in column 1 is employment in the public sector whereas the dependent variable in column 2 is holding a job in health, sport, education, or public administration. In addition to altruism and the usual demographics, we follow Dur and Zoutenbier by including two other self-reported preference measures: laziness and risk aversion. In line with prediction 3, we find in column 1 that workers with stronger altruistic preferences are more likely to end up in the public sector, though the coefficient is marginally insignificant $(p=0.104)$. We find a much higher and significant estimate when employing the alternative definition of a public service job,

system, postal system, other transport, financial institutions, insurance, restaurants, service industries, trash removal, legal services, other services, church, private household. 
see column 2. For each point increase on the altruism scale, the likelihood of employment in health, education, or public administration increases by 3.3 percentage points, which is sizeable given the average likelihood of having such a job of $33.0 \%$. These results as well as the other coefficients are well in line with Dur and Zoutenbier (2015), who used an earlier wave of the German Socio-Economic Panel. It is worth noting that the coefficient for the worker's laziness is marginally insignificant ( $p=0.109$ and $p=0.105$, respectively).

\section{Empirical evidence from the Netherlands}

One limitation of the German data is that the measure of altruism is selfreported. If workers holding public service jobs differ systematically from those holding regular jobs in the way they report their altruism, we may in fact not compare 'similarly altruistic workers' in different job types. Consequently, a difference in observed charitable donations can arise from unobserved differences in true altruism rather than from the substitution between effort in public service jobs and charitable donations. In order to address this potential issue, we complement our empirical analysis of the German cross-sectional data by an analysis of Dutch panel data called LISS. The key advantage of this dataset is that it allows us to observe charitable behavior of the same workers at several points in time, with some of them switching from one job type to the other job type. Assuming that workers' altruistic preferences are stable, ${ }^{17}$ the theoretical prediction is that charitable behavior will change when switching job type, making smaller contributions after moving from a regular to a public service job and vice versa. We use the same data to analyze the effect of a plausibly exogenous change in workers' opportunities to help others on the job on charitable behavior outside work. For this analysis we make use of changes in the composition of the Dutch coalition government together with rich data on government worker's political preferences. The prediction we examine is that government workers whose political preferences align with those of the government have better opportunities to do good on the job, weakening the urge to make charitable contributions outside the job. In contrast to the previous section, we will focus throughout this section on time donations (i.e. volunteering) instead of money donations, because the Dutch LISS panel dataset lacks a precise

\footnotetext{
${ }^{17}$ Carlsson et al. (2014) find evidence that pro-social preferences are stable over long periods of time.
} 
measure of the latter.

\subsection{Data and Empirical Strategy}

The Longitudinal Internet Studies for the Social sciences (LISS) panel is an unbalanced panel consisting of approximately 8,000 individuals. Participants are selected through random sampling from the population register of Statistics Netherlands. Individuals complete online questionnaires every month, and are paid for each completed questionnaire. The first wave was conducted in 2008 and the most recent wave was conducted in 2017. The panel includes modules on Social Integration and Leisure, Work and Schooling, Personality, and Politics and Values. Each of these modules are administered once a year. For our analysis we use data from the years 2008 to 2015.

The key variables that we use in our analysis are sector of employment and the number of hours spent on voluntary work on average per week. Sector of employment is the respondent's answer to the question "In what type of organization do you work?" which is either "public or semi-public sector" or "private company". The number of hours spent volunteering is measured by the question "All things considered, how much time do you spend on voluntary work per week, on average?"

The econometric specification that we use to estimate the effect of job type on volunteering reads:

$$
V_{i, t}=\alpha_{i}+\beta P_{i, t}+\psi X_{i, t}+\tau_{t}+\varepsilon_{i, t}
$$

where $V_{i, t}$ is average weekly hours of volunteering of person $i$ in time period $t$; $\alpha_{i}$ is the individual fixed effect; $P_{i, t}$ a dummy variable that equals one if the worker has a job in the public or semi-public sector; $X_{i, t}$ is a vector of timevarying control variables; and $\tau_{t}$ is the time fixed effect. We estimate (8) using Ordinary Least Squares (OLS) and cluster the standard errors at the individual level to correct for correlation of the error term $\varepsilon_{i, t}$ for individuals over time. ${ }^{18}$ In the spirit of our theoretical model, we predict that $\beta<0$, i.e. workers spend less time on voluntary work when holding a job in the public sector than when holding a job in the private sector. While we always include the individual and time fixed effects, we will run regressions with

\footnotetext{
${ }^{18}$ We also estimated a fixed effects Poisson specification with robust standard errors. The results do not differ much from those estimated using OLS and are available upon request.
} 
and without the time-varying controls for net monthly income, work hours, commuting time (in minutes), and tenure (in years). ${ }^{19}$

The estimate for $\beta$ that we obtain from panel regression (8) relies on variation in volunteering of workers who have switched job type during the sample period. Since switching job type is at least partly endogenous, the estimated $\beta$ may suffer from omitted variable bias and reversed causality problems. Therefore, we also use the Dutch panel data to analyze the effect of a plausibly exogenous change in workers' opportunities to help others on the job on volunteering outside of work. Following Zoutenbier (2016) we use changes in the composition of the Dutch coalition government combined with detailed data on government workers' political preferences. The key idea is that government workers have more opportunities to do good on the job when the mission of the government is in line with their own mission preferences. Consequently, government workers will exert more effort on the job and, by the substitution argument, do less hours of voluntary work. ${ }^{20}$ To measure worker's political preferences, we used the question: "For which party did you vote in the parliamentary elections of [22 November 2006 / 9 June 2010 / 12 September 2012]?" Workers are considered to have a mission match if the political party they voted for in the elections is in office in that same time period. Note that we focus here on government workers instead of all public sector workers. The reason is that we expect that the effect of the political parties in office on the work that people do is larger for government workers than for other public sector workers.

In order to estimate the effect of a change in mission match on volunteering by government workers, we estimate the following regression equation:

$$
V_{i, t}=\alpha_{i}+\delta G_{i, t}+\phi M_{i, t}+\gamma\left(G_{i, t} * M_{i, t}\right)+\varphi X_{i, t}+\tau_{t}+\varepsilon_{i, t}
$$

where $V_{i, t}$ and $\alpha_{i}$ are weekly hours of volunteering and the individual fixed effect, respectively; $G_{i, t}$ is a dummy that equals one if the worker is employed as a government worker and zero if employed elsewhere; $M_{i, t}$ is a dummy that equals one if the worker voted for a political party that is in office and zero if the worker voted for another party; and $X_{i, t}$ and $\tau_{t}$ are time-varying controls

\footnotetext{
${ }^{19}$ Control variables that do not or hardly vary over time (such as gender and education) are captured by the individual fixed effects in (8).

${ }^{20}$ See also (3) and (4). These expressions show that charitable donations outside work decline in the effectiveness of on-the-job effort $(\beta)$ for all workers who choose strictly positive donations.
} 
and the time-fixed effect, respectively. Like equation (8), we estimate (9) using OLS and cluster the standard errors at the individual level. We expect that $\gamma<0$, i.e. government workers whose mission preferences match with those of the ruling coalition government volunteer less because they have more opportunities to do good on the job as compared to government workers whose mission preferences conflict with the mission of the government. We do not expect such an effect for non-government workers (i.e. $\phi=0$ ).

Table 8 displays the descriptive statistics for the full sample as well as separately for public sector workers, private sector workers, and government workers. Our full sample consists of 21,395 observations of 6,573 individuals, of which $21.3 \%$ spent some time volunteering. On average respondents volunteer 58 minutes per week. $37.9 \%$ of the respondents is employed in the public sector of which less than a third ( $9.8 \%$ of the full sample) works for the government. Public sector workers on average spend more hours volunteering than private sector workers. The difference in hours volunteering between government workers and private sector workers is negligible. Further, workers in the public sector are older, have fewer children, earn more, work fewer hours, have longer tenure, and spend slightly more time commuting. Similar differences exist between government workers and private sector workers, except for hours at work, which are relatively high for government workers. On average, slightly less than fifty percent of the sample voted for one of the political parties in office, with public sector workers showing the lowest level of mission match. Since the coefficient for the public sector dummy in specification (8) is identified by those people who switch from the public to the private sector or vice versa within the sample period, it is interesting to know how many respondents switch between sectors. Of the 6,573 individuals, 463 switch at least once between 2008 and 2015 (i.e. $7.0 \%$ of the respondents in the sample).

\subsection{Results}

\subsubsection{Job switchers and charitable behavior}

Table 9 shows the results of estimating equation (8), first without and then with time-varying controls. We find a negative coefficient implying that time spent volunteering is about ten minutes lower when holding a public sector job as compared to when holding a private sector job. This difference is, however, not statistically significant. We find similar results when using 
a different definition of a public service job (namely: a job in education, government, or healthcare and welfare) and within the subsamples of highly educated workers and male workers. These findings are available upon request. Table 10 reports the results for the subsample of workers older than 40 years old. The reason for looking at this subsample is that, in contrast to money donations, volunteering can have meaningful private returns in the labor market as well, see e.g. the field-experimental evidence in Baert and Vujić (2016) and the references therein. Volunteering may enable one to obtain skills that are relevant in the labor market. Moreover, volunteering can be used as a signal to prospective employers about one's personality (Heinz and Schumacher 2017). For older workers, these considerations may well play a less important role in choosing how many hours to do voluntary work. Table 10 shows that among this subsample we find stronger support for our key prediction: When working in the public sector, older workers do on average more than half an hour less voluntary work per week than when working in the private sector. This difference is statistically significant at the 10 percent level.

\subsubsection{Match of mission preferences and charitable behavior}

As a final test of our theoretical prediction, we use another source of variation, namely in the opportunities of government workers to help others on the job, by exploiting plausibly exogenous variation in the composition of the Dutch coalition government. We follow Zoutenbier (2016) who used the same data to analyze the effect of a match of mission preferences on job satisfaction of government workers. Like him, we assume that workers have a match of mission preferences with the government when they voted for a political party that is in office. Assuming that such workers are better able to help others on the job, the substitution argument predicts that government workers with a match in mission preferences volunteer less as compared to government workers without a match in mission preferences.

In order to test this prediction, we estimate equation (9) and report the results for the full sample in columns 1 and 2 of Table 11. We find that having voted for one of the political parties that is in office goes hand in hand with slightly more volunteering by non-government workers, but with less volunteering by government workers. The latter difference amounts to about 15 minutes less per week. This result is robust to including controls and is statistically significant at the 10 percent level. In column 3 and 4 of 
Table 11 we estimate equation (9) for the sample of workers older than 40. We find that the difference in the effect of matching mission preferences on government and non-government workers' volunteering are somewhat larger for this subsample, amounting to about 22 minutes of voluntary work per week, and statistically significant at the 5 percent level.

\section{Concluding Remarks}

We have studied the role of workers' altruistic preferences in occupational choice, on-the-job effort provision, and charitable donations. We developed a simple model producing three key predictions: 1) Given job type, workers with stronger altruistic preferences make higher donations to charity; 2) Given workers' altruism, those working in a public service job (i.e. a job that involves making a contribution to society) donate less to charity than workers in a regular job; and 3) Workers with stronger altruistic preferences are more likely to take a public service job. We examined two datasets (a cross-section from Germany and a panel from the Netherlands) and found some support for our predictions. Our analysis implies that we should be careful with using charitable donations as a proxy for altruistic preferences in studies that compare workers in different sectors. Indeed, our theory predicts and the evidence indicates that workers in public service jobs are more altruistic, and yet make smaller donations to charity than their empirical counterparts in regular jobs. The reason suggested by our theory is a simple substitution argument: Since workers in public service jobs serve the public interest on the job, they are less inclined to make substantial charitable donations outside of work.

In our theoretical model, workers differed not only in altruism, but also in their preference for other job (dis)amenities specific to public service jobs, such as job protection or flexible working hours. In future work, we wish to study how the provision of these (dis)amenities affects the self-selection of worker types to public service jobs. Another interesting avenue for theoretical research would be to allow for heterogeneity in job-specific ability. In such a model, some highly altruistic workers may forego the opportunity to serve the public interest in a public service job, because their high productivity and hence high earnings - in a regular job enable them to serve the public interest better by making high donations to charity. There is some anecdotal 
evidence for this. ${ }^{21}$

Regarding empirical work, it would be interesting to follow workers over time when they switch job types for exogenous reasons such as plant closures. The lab may also provide a useful test bed for more directly testing the substitutability between on-the-job contributions to society and charitable donations (see e.g. Gerhards 2015, Banuri and Keefer 2016, Cassar 2016b, and Carpenter and Gong 2016).

\footnotetext{
${ }^{21}$ The New York Times (4 April 2015) reports about Matt Wage who took a job at an arbitrage trading firm on Wall Street. "Wage reasoned that if he took a high-paying job in finance, he could contribute more to charity. Sure enough, he says that in 2013 he donated more than $\$ 100,000$, roughly half his pretax income."
} 


\section{References}

[1] Abeler, J., Becker, A., \& Falk, A. (2014). Representative evidence on lying costs. Journal of Public Economics, 113, 96-104.

[2] Abeler, J., Nosenzo, D., Raymond, C. (2016). Preferences for truthtelling. IZA Discussion Paper No. 10188.

[3] Alatas, V., Cameron, L., Chaudhuri, A., Erkal, N., \& Gangadharan, L. (2009). Subject pool effects in a corruption experiment: A comparison of Indonesian public servants and Indonesian students. Experimental Economics, 12(1), 113-132.

[4] Aldashev, G., Jaimovich, E., \& Verdier, T. (2016). Small is beautiful: Motivational allocation in the non-profit sector. Journal of the European Economic Association, forthcoming.

[5] Andreoni, J. (1990). Impure altruism and donations to public goods: A theory of warm-glow giving. Economic Journal, 100, 464-477.

[6] Andreoni, J., \& Miller, J. (2002). Giving according to GARP: An experimental test of the consistency of preferences for altruism. Econometrica, $70(2), 737-753$.

[7] Ayaita, O.A., Gülal, F., \& Yang, P. (2017). Where does the good shepherd go? Civic virtue and sorting into public sector employment. Swiss Leading House Working Paper No. 134.

[8] Baert, S., \& Vujić, S. (2016). Does it pay to care? Prosocial engagement and employment opportunities. IZA Discussion Paper No. 9649.

[9] Banerjee, R., Baul, T., \& Rosenblat, T. (2015), On self selection of the corrupt into the public sector. Economics Letters, 127: 43-46.

[10] Banuri, S., \& Keefer, P. (2016). Pro-social motivation, effort and the call to public service. European Economic Review, 83, 139-164.

[11] Barfort, S., Harmon, N.A., Hjorth, F, Olsen, A.L. (2017). Sustaining honesty in public service: The role of selection. Working paper, London School of Economics. 
[12] Barigozzi, F., \& Burani, N. (2016). Screening workers for ability and motivation. Oxford Economic Papers, 68(2), 627-650.

[13] Becker, A., Deckers, T., Dohmen, T., Falk, A., \& Kosse, F. (2012). The relationship between economic preferences and psychological personality measures. Annual Review of Economics, 4, 453-478.

[14] Beckman, S.R., J.P. Formby, W.J. Smith, \& B. Zheng (2002). Envy, malice, and Pareto efficiency: An experimental examination. Social Choice and Welfare, 19(2), 349-367.

[15] Bekkers, R., \& Wiepking, P. (2011). Who gives? A literature review of predictors of charitable giving part one: religion, education, age and socialisation. Voluntary Sector Review, 2(3), 337-365.

[16] Besley, T., \& Ghatak, M. (2005). Competition and incentives with motivated agents. American Economic Review, 95(3): 616-636.

[17] Besley, T., \& Ghatak, M. (2017). Profit with Purpose? A Theory of Social Enterprise. American Economic Journal: Economic Policy, 9(3): 19-58.

[18] Brekke, K.A., \& Nyborg, K. (2008). Attracting responsible employees: Green production as labor market screening. Resource and Energy Economics, 30(4), 509-526.

[19] Brewer, G.A. (2003). Building social capital: Civic attitudes and behavior of public servants. Journal of Public Administration Research and Theory, 13(1), 5-26.

[20] Burgess, S., \& Metcalfe, P. (1999). The use of incentive schemes in the public and private sectors: Evidence from British establishments. CMPO Working Paper 99/015.

[21] Buurman, M., Delfgaauw, J., Dur, R., \& Van den Bossche, S. (2012). Public sector employees: Risk averse and altruistic? Journal of Economic Behavior \& Organization, 83(3), 279-291.

[22] Carlsson, F., Johansson-Stenman, O., \& Nam, P. K. (2014). Social preferences are stable over long periods of time. Journal of Public Economics, 117, 104-114. 
[23] Carpenter, J., \& Myers, C. K. (2010). Why volunteer? Evidence on the role of altruism, image, and incentives. Journal of Public Economics, 94(11), 911-920.

[24] Carpenter, J., \& Gong, E. (2016). Motivating agents: How much does the mission matter? Journal of Labor Economics, 34(1), 211-236.

[25] Cassar, L. (2016a). Optimal contracting with endogenous project mission. CESifo working paper 6181.

[26] Cassar, L. (2016b). Job mission as a substitute for monetary incentives: Experimental evidence. Management Science, forthcoming.

[27] Christensen, R.K., \& Wright, B.E. (2011). The effects of public service motivation on job choice decisions: Disentangling the contributions of person-organization fit and person-job fit. Journal of Public Administration Research and Theory, 21(4), 723-743.

[28] Clemens, M.A. (2017). The meaning of failed replications: A review and proposal. Journal of Economic Surveys, 31(1), 326-342.

[29] Dal Bó, E., Finan, F., \& Rossi, M.A. (2013). Strengthening state capabilities: The role of financial incentives in the call to public service. Quarterly Journal of Economics, 128(3), 1169-1218.

[30] Delfgaauw, J., \& Dur, R. (2007). Signaling and screening of workers' motivation. Journal of Economic Behavior $\& 5$ Organization, 62(4), 605624.

[31] Delfgaauw, J., \& Dur, R. (2008). Incentives and workers' motivation in the public sector. Economic Journal, 118(525), 171-191.

[32] Dur, R., \& Zoutenbier, R. (2014). Working for a good cause. Public Administration Review, 74(2), 144-155.

[33] Dur, R., \& Zoutenbier, R. (2015). Intrinsic motivations of public sector employees: Evidence for Germany. German Economic Review, 16(3), 343-366.

[34] Falk, A., Fehr, E. and Fischbacher, U. (2005). Driving forces behind informal sanctions. Econometrica, 73(6), 2017-2030. 
[35] Falk, A., Becker, A., Dohmen, T., Huffman, D., Sunde, U. (2016), The preference survey module: A validated instrument for measuring risk, time, and social preferences. IZA Discussion Paper No. 9674.

[36] Francois, P. (2000). 'Public service motivation' as an argument for government provision. Journal of Public Economics, 78(3), 275-299.

[37] Francois, P. (2007). Making a difference. RAND Journal of Economics, $38(3), 714-732$.

[38] Francois, P., \& Vlassopoulos, M. (2008). Pro-social motivation and the delivery of social services. CESifo Economic Studies, 54(1), 22-54.

[39] Gerhards, L. (2015), The incentive effects of missions - Evidence from experiments with NGO employees and students. European Economic Review, 79, 252-262.

[40] Gregg, P., Grout, P.A., Ratcliffe, A., Smith, S., \& Windmeijer, F. (2011). How important is pro-social behaviour in the delivery of public services? Journal of Public Economics, 95(7), 758-766.

[41] Hanna, R., \& Wang S. (2017). Dishonesty and selection into public service: Evidence from India. American Economic Journal: Economic Policy, 9(3), 262-290.

[42] Heinz, M., \& Schumacher, H. (2017). Signaling cooperation. European Economic Review, 98, 199-216.

[43] Houston, D.J. (2006). "Walking the walk" of public service motivation: Public employees and charitable gifts of time, blood, and money. Journal of Public Administration Research and Theory, 16(1), 67-86.

[44] Houston, D.J. (2011). Implications of occupational locus and focus for public service motivation: Attitudes toward work motives across nations. Public Administration Review, 71(5), 761-771.

[45] ISSP Research Group (2017). International Social Survey Programme: Work Orientations IV - ISSP 2015. GESIS Data Archive, Cologne. ZA6770 Data file Version 1.0.0, doi:10.4232/1.12744. 
[46] Kjeldsen, A.M., \& Jacobsen, C.B. (2012). Public service motivation and employment sector: Attraction or socialization? Journal of Public Administration Research and Theory, 23(4), 899-926.

[47] Lee, Y.J. (2012). Behavioral implications of public service motivation: Volunteering by public and nonprofit employees. American Review of Public Administration, 42(1), 104-121.

[48] Lewis, G.B., \& Frank, S.A. (2002). Who wants to work for the government? Public Administration Review, 62(4), 395-404.

[49] List, J.A., \& Price, M.K. (2012). Charitable giving around the world: Thoughts on how to expand the pie. CESifo Economic Studies, 58(1), $1-30$.

[50] Lockwood, B.B., Nathanson, C.G., \& Weyl, E.G. (2017). Taxation and the Allocation of Talent. Journal of Political Economy, 125(5), 16351682 .

[51] Manna, E. (2016). Customer-oriented employees: Blessing or curse for firms? Journal of Economics \& Management Strategy, forthcoming.

[52] Merritt, A.C., Effron, D.A., \& Monin, B. (2010). Moral self-licensing: When being good frees us to be bad. Social and Personality Psychology Compass, 4(5), 344-357.

[53] Mesch, D.J., Rooney, P. M., Steinberg, K.S., \& Denton, B. (2006). The effects of race, gender, and marital status on giving and volunteering in Indiana. Nonprofit and Voluntary Sector Quarterly, 35(4), 565-587.

[54] Perry, J.L., Hondeghem, A., \& Wise, L.R. (2010). Revisiting the motivational bases of public service: Twenty years of research and an agenda for the future. Public Administration Review, 70(5), 681-690.

[55] Perry, J.L., \& Wise, L.R. (1990). The motivational bases of public service. Public Administration Review, 50, 367-373.

[56] Perry, J.L., \& Vandenabeele, W. (2015). Public service motivation research: Achievements, challenges, and future directions. Public Administration Review, 75(5), 692-699. 
[57] Piatak, J.S. (2015). Altruism by Job Sector: Can Public Sector Employees Lead the Way in Rebuilding Social Capital? Journal of Public Administration Research and Theory, 25(3), 877-900.

[58] Piper, G., \& Schnepf, S. V. (2008). Gender differences in charitable giving in Great Britain. Voluntas: International Journal of Voluntary and Nonprofit Organizations, 19(2), 103-124.

[59] Podgursky, M. (2007). Teams versus bureaucracies: Personnel policy, wage-setting, and teacher quality in traditional public, charter, and private schools. In: Mark Berends, Matthew G. Springer, Herbert J. Walberg (Eds.), Charter School Outcomes, London: Routledge, 61-84.

[60] Prendergast, C. (2007). The motivation and bias of bureaucrats. American Economic Review, 97, 180-196.

[61] Rotolo, T., \& Wilson, J. (2006). Employment sector and volunteering: The contribution of nonprofit and public sector workers to the volunteer labor force. Sociological Quarterly, 47(1), 21-40.

[62] Steijn, B. (2008). Person-environment fit and public service motivation. International Public Management Journal, 11(1), 13-27.

[63] Tonin, M., \& Vlassopoulos, M. (2010). Disentangling the sources of prosocially motivated effort: A field experiment. Journal of Public Economics, 94(11), 1086-1092.

[64] Tonin, M., \& Vlassopoulos, M. (2015). Are public sector workers different? Cross-European evidence from elderly workers and retirees. IZA Journal of Labor Economics, 4(11), 1-21.

[65] Vandenabeele, W. (2008). Government calling: Public service motivation as an element in selecting government as an employer of choice. Public Administration, 86(4), 1089-1105.

[66] Wagner, G.G., Frick, J.R., \& Schupp, J. (2007). The German SocioEconomic Panel Study (SOEP) - Scope, evolution and enhancements, Schmollers Jahrbuch, 127, 139-169.

[67] Wright, B.E., \& Christensen, R.K. (2010). Public service motivation: A test of the job attraction-selection-attrition model. International Public Management Journal, 13(2), 155-176. 
[68] Zoutenbier, R. (2016). The impact of matching mission preferences on well-being at work. Economics of Governance, 17(3), 295-315. 


\section{Tables and Figures}

Table 1: Opportunities to help others and to be useful to society on the job, by sector (mean values on a 5-point scale)

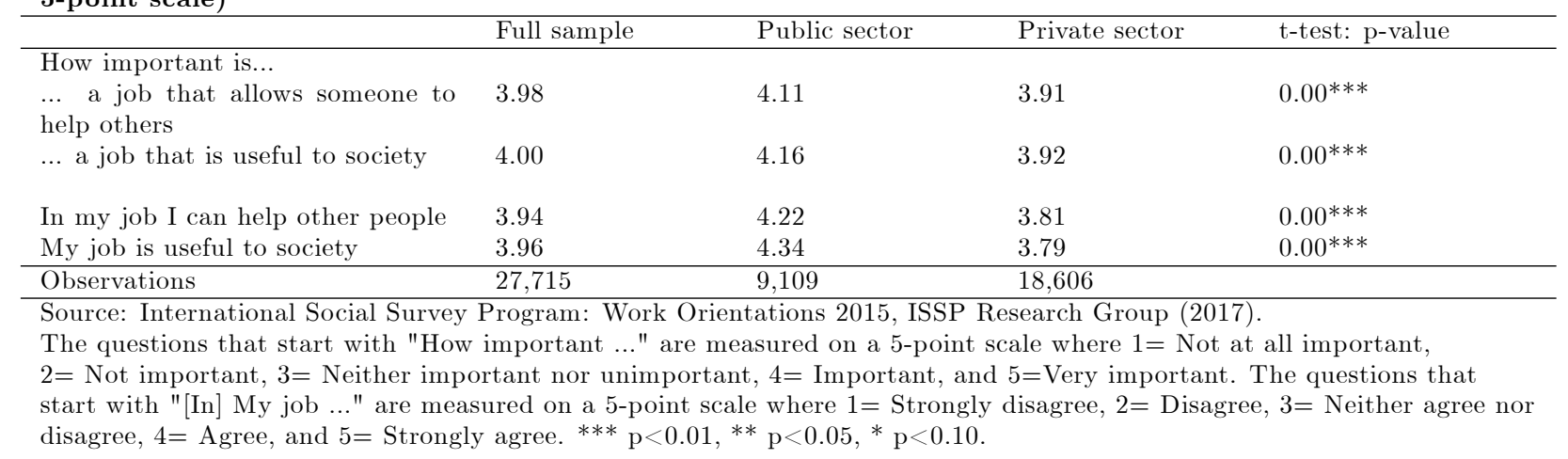


Table 2: Descriptive Statistics GSOEP

\begin{tabular}{|c|c|c|c|}
\hline & Total & Public $(26,2 \%)$ & Private $(73.8 \%)$ \\
\hline Donations: mean & 111.20 & 121.95 & 107.37 \\
\hline standard deviation & 522.26 & 411.40 & 556.38 \\
\hline Altruism (1): \% & 0.2 & 0.2 & 0.2 \\
\hline Altruism (2): \% & 6.6 & 5.2 & 7.1 \\
\hline Altruism (3): \% & 68.9 & 69.1 & 68.9 \\
\hline Altruism (4): \% & 24.3 & 25.5 & 23.8 \\
\hline Altruism: mean & 3.17 & 3.20 & 3.16 \\
\hline standard deviation & 0.54 & 0.53 & 0.54 \\
\hline Age: mean & 45.5 & 46.4 & 45.2 \\
\hline standard deviation & 11.1 & 10.8 & 11.2 \\
\hline Female: $\%$ & 48.8 & 56.3 & 46.1 \\
\hline Yearly income: mean & 21287.17 & 23077.86 & 20650.17 \\
\hline standard deviation & 17324.48 & 12535.22 & 18694.91 \\
\hline Nr. of children in $\mathrm{HH}$ : mean & 0.55 & 0.50 & 0.57 \\
\hline standard deviation & 0.87 & 0.84 & 0.88 \\
\hline Married: \% & 64.2 & 64.5 & 64.1 \\
\hline Single: \% & 22.2 & 20.8 & 22.7 \\
\hline Widowed: \% & 1.6 & 1.5 & 1.7 \\
\hline Divorced: \% & 9.8 & 10.9 & 9.4 \\
\hline Separated: $\%$ & 2.2 & 2.3 & 2.1 \\
\hline Education: less than HS: \% & 7.1 & 5.5 & 7.7 \\
\hline Education: HS: \% & 63.0 & 47.3 & 68.6 \\
\hline Education: more than HS: $\%$ & 29.9 & 47.2 & 23.7 \\
\hline Tenure: mean & 12.4 & 15.7 & 11.2 \\
\hline standard deviation & 10.6 & 11.7 & 9.9 \\
\hline Religion: other religion: \% & 0.3 & 0.3 & 0.2 \\
\hline Islamic: \% & 1.8 & 1.0 & 2.1 \\
\hline Protestant: \% & 30.9 & 33.3 & 30.1 \\
\hline Catholic: \% & 28.0 & 30.2 & 27.3 \\
\hline Other christian: \% & 1.9 & 1.5 & 2.0 \\
\hline Not religious: \% & 37.1 & 33.7 & 38.3 \\
\hline Observations & 7527 & 1975 & 5552 \\
\hline
\end{tabular}




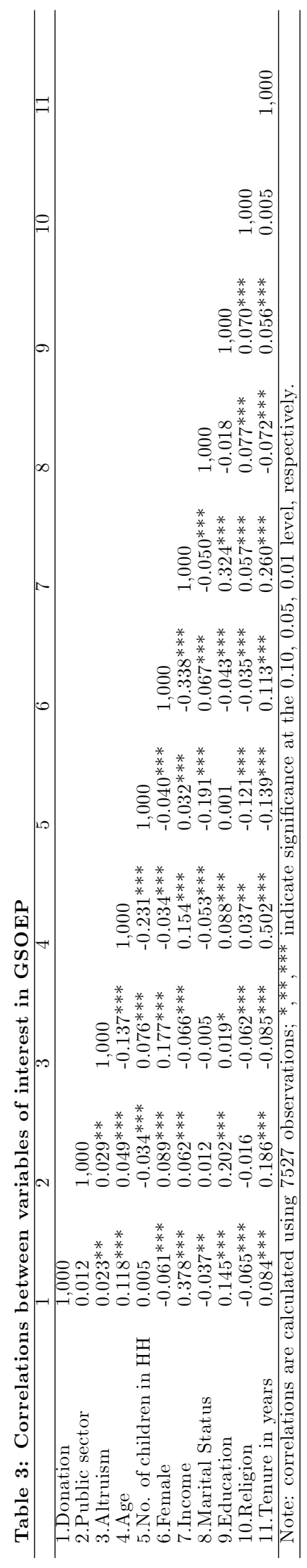


Table 4: OLS regression comparing public and private sector workers Dependent variable: Donations

\begin{tabular}{|c|c|c|}
\hline Public Sector & $\begin{array}{l}-32.51^{* *} \\
(14.08)\end{array}$ & $\begin{array}{l}-1.57 \\
(13.52)\end{array}$ \\
\hline Altruism (1) & $\begin{array}{l}-117.85 \\
(123.72)\end{array}$ & $\begin{array}{l}-81.55 \\
(117.47)\end{array}$ \\
\hline Altruism (2) & $\begin{array}{l}-56.91^{* *} \\
(24.02)\end{array}$ & $\begin{array}{l}-58.86^{* * *} \\
(22.81)\end{array}$ \\
\hline Altruism (4) & $\begin{array}{l}29.88^{* *} \\
(14.12)\end{array}$ & $\begin{array}{l}27.36^{* *} \\
(13.40)\end{array}$ \\
\hline Age & $\begin{array}{l}-13.68^{* * *} \\
(3.94)\end{array}$ & $\begin{array}{l}-13.43^{* * *} \\
(3.81)\end{array}$ \\
\hline Age*Age & $\begin{array}{l}0.21^{* * * *} \\
(0.04)\end{array}$ & $\begin{array}{l}0.20^{* * * *} \\
(0.04)\end{array}$ \\
\hline No. of children in $\mathrm{HH}$ & $\begin{array}{l}25.13^{* * *} \\
(7.94)\end{array}$ & $\begin{array}{l}16.35^{* *} \\
(7.60)\end{array}$ \\
\hline Female & $\begin{array}{l}-52.30^{* * *} \\
(12.24)\end{array}$ & $\begin{array}{l}-14.26 \\
(12.90)\end{array}$ \\
\hline Education: HS & $\begin{array}{l}30.77 \\
(23.63)\end{array}$ & $\begin{array}{l}24.02 \\
(22.50)\end{array}$ \\
\hline Education: More than HS & $\begin{array}{l}195.88^{* * *} \\
(25.17)\end{array}$ & $\begin{array}{l}118.90^{* * *} \\
(24.79)\end{array}$ \\
\hline Tenure in years & $\begin{array}{l}1.60^{* *} \\
(0.66)\end{array}$ & $\begin{array}{l}0.67 \\
(0.66)\end{array}$ \\
\hline Constant & $\begin{array}{l}430.23^{* * *} \\
(152.51)\end{array}$ & $\begin{array}{l}425.80^{* * *} \\
(145.10)\end{array}$ \\
\hline Control for Income & $\mathrm{NO}$ & YES \\
\hline Control for marital status & YES & YES \\
\hline Control for religion & YES & YES \\
\hline Observations & 7527 & 7527 \\
\hline
\end{tabular}

Standard errors in parentheses, ${ }^{* * *} \mathrm{p}<0.01,{ }^{* *} \mathrm{p}<0.05,{ }^{*} \mathrm{p}<0.10$. Baseline category Altruism:3, Education: Less than High school. Income is included using 10 dummies for income categories with a range of 10,000, i.e. [0-10,000]; [10,001-20,000];

$\ldots ;[100,001$ and higher]. 
Table 5: OLS comparing public service industries with the other industries Dependent variable: Donations

\begin{tabular}{|c|c|c|c|c|}
\hline Public Service & $\begin{array}{l}-13.72 \\
(12.88)\end{array}$ & $\begin{array}{l}-1.11 \\
(12.34)\end{array}$ & & \\
\hline Public Administration & & & $\begin{array}{l}-55.23^{* * *} \\
(20.84)\end{array}$ & $\begin{array}{l}-26.66 \\
(20.08)\end{array}$ \\
\hline Education & & & $\begin{array}{l}3.01 \\
(19.51)\end{array}$ & $\begin{array}{l}27.49 \\
(18.68)\end{array}$ \\
\hline Health & & & $\begin{array}{l}1.74 \\
(17.58)\end{array}$ & $\begin{array}{l}-5.29 \\
(16.84)\end{array}$ \\
\hline Altruism (1) & $\begin{array}{l}-117.38 \\
(121.00)\end{array}$ & $\begin{array}{l}-83.71 \\
(115.66)\end{array}$ & $\begin{array}{l}-115.85 \\
(120.97)\end{array}$ & $\begin{array}{l}-84.60 \\
(115.65)\end{array}$ \\
\hline Altruism (2) & $\begin{array}{l}-51.11^{* *} \\
(23.04)\end{array}$ & $\begin{array}{l}-54.08^{* *} \\
(22.03)\end{array}$ & $\begin{array}{l}-50.38^{* *} \\
(23.04)\end{array}$ & $\begin{array}{l}-54.06^{* *} \\
(22.03)\end{array}$ \\
\hline Altruism (4) & $\begin{array}{l}32.53^{* *} \\
(13.54)\end{array}$ & $\begin{array}{l}29.70^{* *} \\
(12.94)\end{array}$ & $\begin{array}{l}31.13^{* *} \\
(13.54)\end{array}$ & $\begin{array}{l}28.59^{* *} \\
(12.95)\end{array}$ \\
\hline Age & $\begin{array}{l}-17.58^{* * *} \\
(3.81)\end{array}$ & $\begin{array}{l}-17.29^{* * *} \\
(3.70)\end{array}$ & $\begin{array}{l}-17.48^{* * *} \\
(3.81)\end{array}$ & $\begin{array}{l}-17.19^{* * *} \\
(3.70)\end{array}$ \\
\hline Age*Age & $\begin{array}{l}0.26^{* * *} \\
(0.04)\end{array}$ & $\begin{array}{l}0.24^{* * *} \\
(0.04)\end{array}$ & $\begin{array}{l}0.25^{* * *} \\
(0.04)\end{array}$ & $\begin{array}{l}0.24^{* * *} \\
-0.04\end{array}$ \\
\hline No. of children & $\begin{array}{l}27.05^{* * * *} \\
(7.63)\end{array}$ & $\begin{array}{l}18.26^{* *} \\
(7.35)\end{array}$ & $\begin{array}{l}26.71^{* * *} \\
(7.63)\end{array}$ & $\begin{array}{l}18.17^{* *} \\
(7.35)\end{array}$ \\
\hline Female & $\begin{array}{l}-49.58^{* * *} \\
(12.04)\end{array}$ & $\begin{array}{l}-11.66 \\
(12.69)\end{array}$ & $\begin{array}{l}-52.94^{* * *} \\
(12.12)\end{array}$ & $\begin{array}{l}-12.62 \\
(12.73)\end{array}$ \\
\hline Education: HS & $\begin{array}{l}33.83 \\
(22.74)\end{array}$ & $\begin{array}{l}25.61 \\
(21.80)\end{array}$ & $\begin{array}{l}33.04 \\
(22.74)\end{array}$ & $\begin{array}{l}25.33 \\
(21.80)\end{array}$ \\
\hline Education: More than HS & $\begin{array}{l}185.73^{\text {*** }} \\
(24.38)\end{array}$ & $\begin{array}{l}113.97^{* * *} \\
(24.19)\end{array}$ & $\begin{array}{l}185.69^{* * * *} \\
(24.41)\end{array}$ & $\begin{array}{l}111.51^{* * *} \\
(24.22)\end{array}$ \\
\hline Tenure in years & $\begin{array}{l}1.47^{* *} \\
(0.62)\end{array}$ & $\begin{array}{l}0.70 \\
(0.63)\end{array}$ & $\begin{array}{l}1.72^{* * *} \\
(0.63)\end{array}$ & $\begin{array}{l}0.81 \\
(0.64)\end{array}$ \\
\hline Constant & $\begin{array}{l}468.98^{* * *} \\
(148.71)\end{array}$ & $\begin{array}{l}476.22^{* * *} \\
(142.46)\end{array}$ & $\begin{array}{l}467.03^{* * *} \\
(148.67)\end{array}$ & $\begin{array}{l}474.78^{* * *} \\
(142.44)\end{array}$ \\
\hline Control for Income & $\mathrm{NO}$ & YES & NO & YES \\
\hline Control for marital status & YES & YES & YES & YES \\
\hline Control for religion & YES & YES & YES & YES \\
\hline Observations & 7348 & 7348 & 7348 & 7348 \\
\hline
\end{tabular}


Table 6: OLS regression comparing public and private sector workers Dep. variable: Donations Sample: Highly Educated Sample: Males

\begin{tabular}{|c|c|c|c|c|}
\hline Public Sector & $\begin{array}{l}-92.27^{* *} \\
(39.27)\end{array}$ & $\begin{array}{l}-23.84 \\
(37.77)\end{array}$ & $\begin{array}{l}-75.68^{* * *} \\
(27.37)\end{array}$ & $\begin{array}{l}-18.34 \\
(25.86)\end{array}$ \\
\hline Altruism (1) & $\begin{array}{l}-99.46 \\
(498.50)\end{array}$ & $\begin{array}{l}-37.91 \\
(467.92)\end{array}$ & $\begin{array}{l}-124.94 \\
(174.79)\end{array}$ & $\begin{array}{l}-87.90 \\
(163.47)\end{array}$ \\
\hline Altruism (2) & $\begin{array}{l}-139.01^{*} \\
(75.90)\end{array}$ & $\begin{array}{l}-158.54^{* *} \\
(71.27)\end{array}$ & $\begin{array}{l}-65.44^{*} \\
(37.66)\end{array}$ & $\begin{array}{l}-67.50^{*} \\
(35.24)\end{array}$ \\
\hline Altruism (4) & $\begin{array}{l}73.47^{*} \\
(43.35)\end{array}$ & $\begin{array}{l}68.14^{*} \\
(40.71)\end{array}$ & $\begin{array}{l}46.20 \\
(28.72)\end{array}$ & $\begin{array}{l}43.85 \\
(26.88)\end{array}$ \\
\hline Age & $\begin{array}{l}-26.04^{* *} \\
(12.85)\end{array}$ & $\begin{array}{l}-38.21^{* * *} \\
(12.24)\end{array}$ & $\begin{array}{l}-21.43^{* * *} \\
(6.897)\end{array}$ & $\begin{array}{l}-23.55^{* * *} \\
(6.69)\end{array}$ \\
\hline Age*Age & $\begin{array}{l}0.41^{* * *} \\
-0.13\end{array}$ & $\begin{array}{l}0.52^{* * *} \\
(0.13)\end{array}$ & $\begin{array}{l}0.32^{* * *} \\
-0.07\end{array}$ & $\begin{array}{l}0.32^{* * * *} \\
(0.07)\end{array}$ \\
\hline No. of children & $\begin{array}{l}42.17^{*} \\
(23.51)\end{array}$ & $\begin{array}{l}27.17 \\
(22.32)\end{array}$ & $\begin{array}{l}20.01 \\
(14.40)\end{array}$ & $\begin{array}{l}2.50 \\
(13.56)\end{array}$ \\
\hline Female & $\begin{array}{l}-121.34^{* * *} \\
(38.07)\end{array}$ & $\begin{array}{l}-21.59 \\
(39.73)\end{array}$ & & \\
\hline Education: High School (HS) & & & $\begin{array}{l}34.40 \\
(47.34)\end{array}$ & $\begin{array}{l}25.63 \\
(44.34)\end{array}$ \\
\hline Education: More than HS & & & $\begin{array}{l}263.55^{* * *} \\
(50.28)\end{array}$ & $\begin{array}{l}130.70^{* * *} \\
(48.85)\end{array}$ \\
\hline Tenure in years & $\begin{array}{l}3.00 \\
(2.15)\end{array}$ & $\begin{array}{l}1.28 \\
(2.10)\end{array}$ & $\begin{array}{l}1.70 \\
(1.18)\end{array}$ & $\begin{array}{l}0.55 \\
(1.16)\end{array}$ \\
\hline Constant & $\begin{array}{l}475.58 \\
(531.72)\end{array}$ & $\begin{array}{l}573.24 \\
(500.95)\end{array}$ & $\begin{array}{l}787.02^{* * *} \\
(275.76)\end{array}$ & $\begin{array}{l}793.54^{* * *} \\
(259.56)\end{array}$ \\
\hline Control for Income & NO & YES & NO & YES \\
\hline Control for marital status & YES & YES & YES & YES \\
\hline Control for religion & YES & YES & YES & YES \\
\hline Observations & 2,247 & 2,247 & 3,857 & 3,857 \\
\hline
\end{tabular}

Standard errors in parentheses, ${ }^{* * *} \mathrm{p}<0.01,{ }^{* *} \mathrm{p}<0.05,{ }^{*} \mathrm{p}<0.10$. Baseline category Altruism: 3, Education: Less than High School (HS). Income is included using 10 dummies for income categories with a range of 10,000, i.e. [0-10,000]; [10,001-20,000]; ...; [100,001 and higher]. 
Table 7: Linear probability model of selection of workers

\begin{tabular}{|c|c|c|}
\hline Dependent variable: & Public sector & Public service \\
\hline \multirow[t]{2}{*}{ Altruism } & 0.015 & $0.033^{* * *}$ \\
\hline & $(0.009)$ & $(0.010)$ \\
\hline \multirow[t]{2}{*}{ Laziness } & 0.005 & 0.006 \\
\hline & $(0.003)$ & $(0.003)$ \\
\hline \multirow[t]{2}{*}{ Risk aversion } & $0.011^{* * *}$ & $0.008^{* * *}$ \\
\hline & $(0.002)$ & $(0.002)$ \\
\hline \multirow[t]{2}{*}{ Age } & $0.007^{* *}$ & -0.004 \\
\hline & $(0.003)$ & $(0.003)$ \\
\hline \multirow[t]{2}{*}{ Age*Age } & $0.000 * *$ & 0.000 \\
\hline & $(0.000)$ & $(0.000)$ \\
\hline \multirow[t]{2}{*}{ Female } & $0.069^{* * *}$ & $0.213^{* * *}$ \\
\hline & $(0.010)$ & $(0.011)$ \\
\hline \multirow[t]{2}{*}{ German nationality } & $0.082^{* * *}$ & $0.076^{* * *}$ \\
\hline & $(0.026)$ & $(0.027)$ \\
\hline \multirow[t]{2}{*}{ No. of children in $\mathrm{HH}$} & $-0.019^{* * *}$ & -0.007 \\
\hline & $(0.007)$ & $(0.007)$ \\
\hline \multirow[t]{2}{*}{ Education: HS } & -0.015 & 0.033 \\
\hline & $(0.020)$ & $(0.021)$ \\
\hline \multirow[t]{2}{*}{ Education: More than HS } & $0.205^{* * *}$ & $0.301^{* * *}$ \\
\hline & $(0.021)$ & $(0.022)$ \\
\hline \multirow[t]{2}{*}{ Constant } & -0.132 & 0.047 \\
\hline & $(0.094)$ & $(0.099)$ \\
\hline Control for marital status & YES & YES \\
\hline Control for region & YES & YES \\
\hline Observations & 7470 & 7240 \\
\hline
\end{tabular}

Standard errors in parentheses, ${ }^{* * *} \mathrm{p}<0.01,{ }^{* *} \mathrm{p}<0.05,{ }^{*} \mathrm{p}<0.10$.

Baseline category Education: Less than High school. 
Table 8: Descriptive Statistics LISS

\begin{tabular}{lllll}
\hline & Total & Public(37.9\%) & Private(62.1\%) & Government(9.8\%) \\
\hline Volunteering: mean & 0.97 & 1.11 & 0.89 & 0.90 \\
standard deviation & 3.78 & 4.30 & 3.43 & 2.56 \\
Volunteering: \% & $21.3 \%$ & $23.8 \%$ & $19.8 \%$ & $21.3 \%$ \\
& & & & \\
Age: mean & 43.00 & 44.97 & 41.80 & 46.14 \\
standard deviation & 12.05 & 11.61 & 12.16 & 10.89 \\
& & & & \\
Number of children: mean & 1.06 & 1.01 & 1.09 & 0.96 \\
standard deviation & 1.14 & 1.15 & 1.14 & 1.13 \\
& & & & \\
Net income: mean & 1723.85 & 1750.21 & 1707.76 & 2177.25 \\
standard deviation & 3362.78 & 2987.31 & 3572.66 & 4829.18 \\
& & & & \\
Hours at work: mean & 30.22 & 29.20 & 30.85 & 32.24 \\
standard deviation & 14.52 & 13.15 & 15.25 & 12.72 \\
& & & & \\
Distance: mean & 26.57 & 27.27 & 26.14 & 33.01 \\
standard deviation & 22.03 & 21.39 & 22.41 & 24.20 \\
& & & & \\
Tenure: mean & 11.36 & 13.48 & 10.07 & 15.70 \\
standard deviation & 10.49 & 11.15 & 9.84 & 12.03 \\
Mission match: mean & 0.45 & 0.42 & & \\
standard deviation & 0.50 & 0.49 & 0.46 & 0.47 \\
\hline $\begin{array}{l}\text { Observations } \\
\text { Number of individuals }\end{array}$ & 21395 & 8110 & 0.50 & 0.50 \\
\hline
\end{tabular}


Table 9: Fixed effects OLS comparing public and private sector workers Dependent variable: Volunteering

\begin{tabular}{lll}
\hline Public sector & -0.150 & -0.128 \\
& $(0.215)$ & $(0.212)$ \\
Hours at work & & $-0.005^{* *}$ \\
& & $(0.002)$ \\
Net income & -0.000 \\
& $(0.000)$ \\
Commuting time & -0.003 \\
& & $(0.004)$ \\
Tenure & & -0.011 \\
& & $(0.008)$ \\
Individual and time fixed effects & YES & YES \\
\hline Observations & 21395 & 21395 \\
Number of individuals & 6573 & 6573 \\
\hline Standard errors in parenthese, $* * * \mathrm{p}<0.01, * * \mathrm{p}<0.05, * \mathrm{p}<0.10$.
\end{tabular}

Standard errors are clustered on the individual level. 
Table 10: Fixed effects OLS, sample: age $>40$

\begin{tabular}{|c|c|c|}
\hline \multicolumn{3}{|c|}{ Dependent variable: Volunteering } \\
\hline \multirow[t]{2}{*}{ Public sector } & $-0.611^{*}$ & $-0.620^{*}$ \\
\hline & $(0.326)$ & $(0.324)$ \\
\hline \multirow[t]{2}{*}{ Hours at work } & & $-0.009^{* *}$ \\
\hline & & $(0.004)$ \\
\hline \multirow[t]{2}{*}{ Net income } & & -0.000 \\
\hline & & $(0.000)$ \\
\hline \multirow[t]{2}{*}{ Commuting time } & & -0.002 \\
\hline & & $(0.006)$ \\
\hline \multirow[t]{2}{*}{ Tenure } & & $-0.016^{*}$ \\
\hline & & $(0.009)$ \\
\hline Individual and time fixed effects & YES & YES \\
\hline Observations & 12541 & 12541 \\
\hline Number of individuals & 3606 & 3606 \\
\hline
\end{tabular}


Table 11: Fixed effects OLS comparing match and mismatch of mission motivation for government workers

\begin{tabular}{lclll}
\hline Dependent variable: Volunteering & \multicolumn{3}{c}{ Sample: Age $>40$} \\
\hline Government & 0.209 & 0.218 & 0.037 & 0.033 \\
Match & $(0.262)$ & $(0.267)$ & $(0.502)$ & $(0.511)$ \\
& 0.079 & 0.077 & 0.101 & 0.100 \\
Government*Match & $(0.070)$ & $(0.070)$ & $(0.096)$ & $(0.095)$ \\
& $-0.249^{*}$ & $-0.247^{*}$ & $-0.381^{* *}$ & $-0.382^{* *}$ \\
Hours at work & $(0.136)$ & $(0.136)$ & $(0.172)$ & $(0.173)$ \\
& & $-0.005^{* *}$ & & $-0.006^{*}$ \\
Net income & & $(0.002)$ & & $(0.003)$ \\
& & -0.000 & & -0.000 \\
Commuting time & & $(0.000)$ & & $-0.000)$ \\
& & -0.002 & & -0.003 \\
Tenure & & $(0.004)$ & & -0.010 \\
& & -0.008 & & $(0.009)$ \\
Individual and time fixed & YES & $(0.008)$ & & YES \\
effects & & & YES & \\
\hline Observations & 16504 & 16504 & 10752 & 10752 \\
Number of individuals & 5382 & 5382 & 3331 & 3331 \\
\hline Standard ers & & & & \\
\hline
\end{tabular}

Standard errors in parenthese, ${ }^{* * *} \mathrm{p}<0.01,{ }^{* *} \mathrm{p}<0.05,{ }^{*} \mathrm{p}<0.10$. Standard errors are clustered on the individual level. 


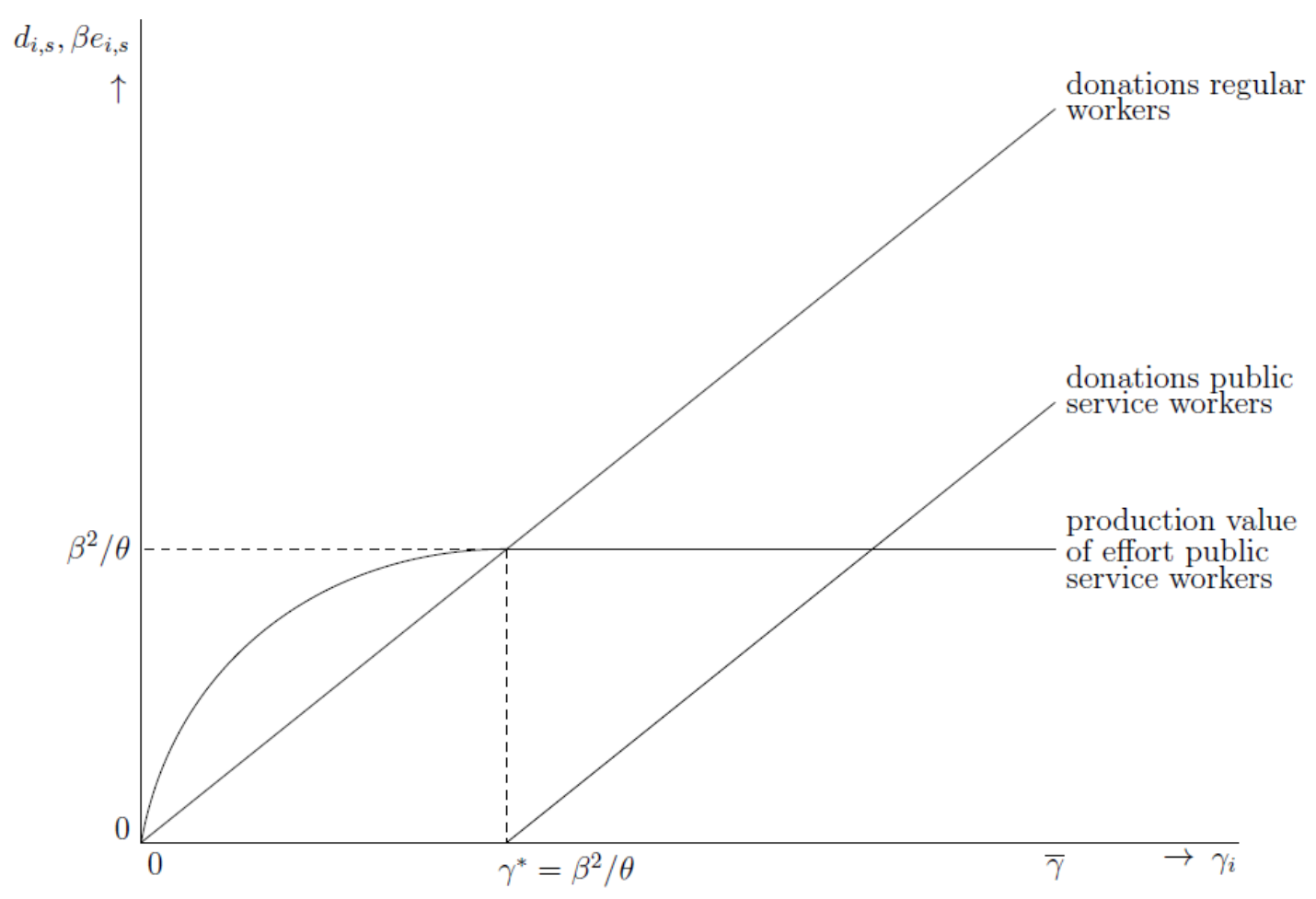

Figure 1: Contributions to the public interest by regular and public service workers for all levels of worker's altruism $\gamma_{i}$. 


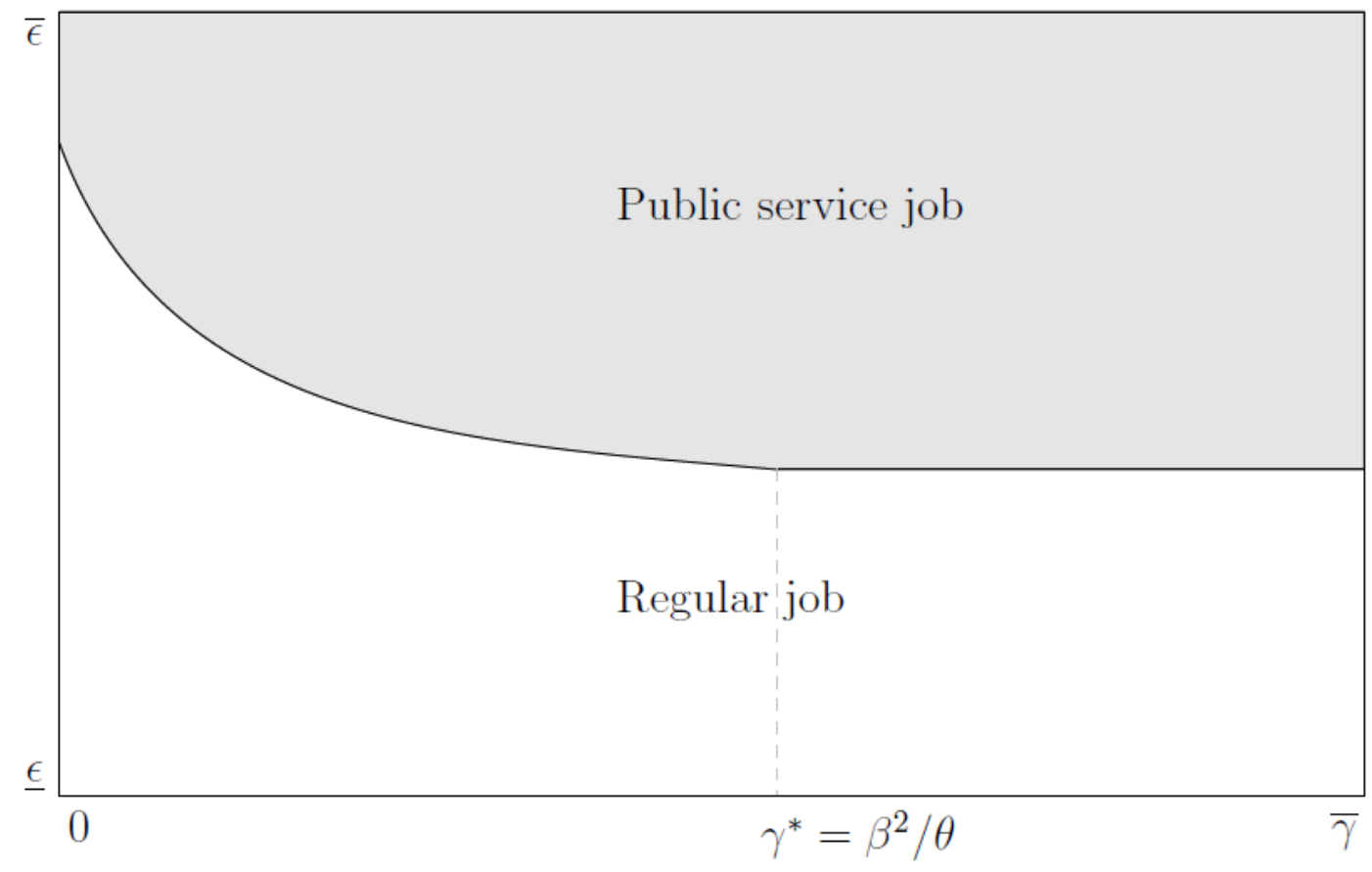

Figure 2: Worker's choice of job type 


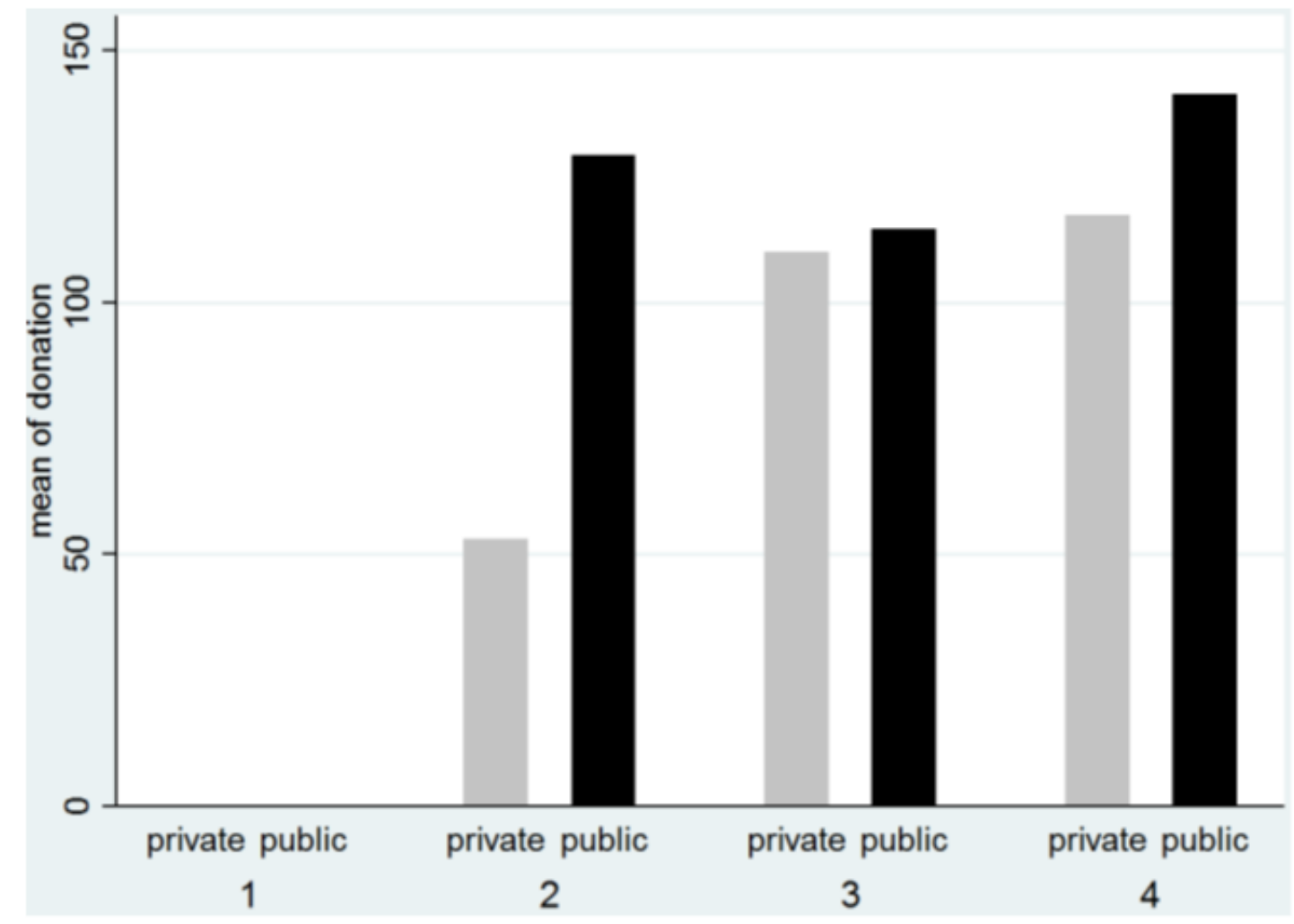

Figure 3: Mean of donations by altruism category and sector of employment. $1,2,3,4$ refer to the respondents' answers to the question: "How important are the following things [being there for others] currently for you?" Answers are given on a four point scale, ranging from "not at all important" (1) to "very important" (4). 